N. Koschechko, PhD (Pedagogical Sciences) Taras Shevchenko National University of Kyiv, Kyiv, Ukraine

\title{
ART-THERAPY RESOURCES IN THE MANAGEMENT OF PEDAGOGICAL CONFLICTS IN UNIVERSITIES OF UKRAINE
}

The article analyses actual ideas on the problem of pedagogical conflict management in universities with the help of art therapy resources. This area of scientific knowledge is designed to help the individual to realize their inner state by creating a visual image, metaphors, symbols, videos (art-therapeutic product). Art therapy is a development in the personality inherent in its creativity, which helps in solving conflicts. Through creative expression, art therapy actualizes personal resources for overcoming pedagogical conflicts and provides an output of accumulated energy (aggression), thus harmonizing the emotional sphere. Creating abstract images, the student finds answers too many topical questions, explores fears and barriers to communication. These images arise unconsciously and spontaneously, which is why anxiety and resistance to self-discovery decrease. This provides a diverse range of tools for dealing with the emotional sphere of the individual. Art therapy provides a specific answer to the global question "How to curb emotions in conflict?". In this context, the content, the historical aspect, the specifics of the use of art therapy in universities are analysed and the essence, characterization, dynamics of pedagogical conflicts are revealed. Types of art therapy in the management of pedagogical conflicts in universities are generalized. According to the questionnaire, students overcome the pedagogical conflicts with the following types of art therapy: music therapy (29\%), phototherapy (25\%), drawing therapy (12\%), bibliotherapy (10\%) (especially in electronic format), dance and movement therapy (7\%), collage (4\%) other types (13\%). They are harmoniously complemented by combined logotherapy with the use of virtual communication of social networks, which, from the students' experience, provides a qualitative constructive result in solving pedagogical conflicts. Performance, drama, media-art therapy in the format of blogging on various online platforms (YouTube, Instagram, Telegram channels) are all separate modern types of art therapy that helps creative expression, self-affirmation, self-actualization and selfhealing of the personality.

Keywords: Art Therapy, Management of Pedagogical Conflicts, University.

Formulation of the problem. Nowadays, Ukrainian universities are reforming, transforming and integrating education, which is accompanied by contradictory, conflicting interaction between participants in the educational process. Pedagogical conflicts have mainly destructive consequences due to the severity of their occurrence, difficult to manage emotions of students and teachers, lack of psycho-hygiene and conflicting competence. Such conflicts can destroy the system of moral standards and values in higher education, significantly reducing the quality of training of future specialists. In the traditional educational paradigm, defending one's point of view by a student (teacher) in response to the authoritarian dominant position of the teacher (administration) has led to a corresponding conflict. Therefore, the old higher education paradigm has proved incapable of creating proper interpersonal relationships in the new society that would contribute to the self-actualization of the individual, his positive constructive development and creative manifestation of man's internal resources. At the same time, the principle of humanization of education implies a qualitative transformation of the positions of the teacher and the student into subjectsubject relations in the personal-partner plane of their cooperation. New quality of activity of high school is impossible without change of character of pedagogical interaction, transition to equal relations of participants of educational process that allows timely realization of pedagogical conflict and its constructive resolution.

Pedagogical conflicts are manifested in the interaction of participants in the educational process (students, teachers, administration) due to the presence of certain contradictions, contradictions in value orientations, attitudes, mutual expectations, tactlessness in communication, destructive actions, insufficient conflictological culture of individuals $[13$, p. 100]. Pedagogical conflicts not only create problems in pedagogical activity, but also serve as a source of development of the organization, small group, and personality in it. Such conflicts reflect the specific way of interaction between the participants in the educational process and become a form of exacerbated internal contradictions, which are the basis for pedagogical conflicts.

In the vast majority, university students have no inner harmony. Instead, they have numerous intrapersonal conflicts that are intensely saturated with polar emotions. Their causes are provoked by various social, economic, political, cultural factors [1]. Students' communication is becoming a key part of this process as one of the most important activities for this age. Student communication is a dominant resource in overcoming conflicts of various types. Students use different methods, techniques and tools to solve them.

Among them, art therapy, which provides a diverse range of tools for dealing with the emotional sphere of personality, has become particularly relevant and effective. It is the feelings and emotions, their manifestation, management, reflection in the pedagogical conflict that becomes an important problem for university students. Contemporary conflictologists are actively addressing this issue and are actively developing effective conflict resolution strategies, models, and algorithms. In the beginning, they are sure to look at ways to reduce the intensity of emotionality, calm, relaxation of the person through spiritual practices, self-training, "rejection" and "deprivation", overcoming emotions that interfere with the rational constructive resolution of conflicts.

Art therapy is the most ancient and natural form of emotional state correction that can be used to relieve the accumulated mental stress, to calm down or just focus. Art therapy provides a specific answer to the global question "How to curb emotions in conflict?" The joint creative search in overcoming the conflict situation of the student and the teacher, realized in the process of art therapy, gives the opportunity to express and reproduce the inner feelings, feelings, doubts, conflicts and hopes, symbolically experiencing once again important events. After all, spontaneous creative activity is able to express the unconscious content of mental life.

In the scientific-pedagogical sense, art therapy is considered as a method of development and change of personality, group or collective through different types and forms of art and creativity. Although the latter is a goal of activity, it is of great importance; however, the first place in art therapy is still given to therapeutic purposes.

Analysis of recent researches and publications. Problems of pedagogical conflicts have been studied by many scholars and have been presented in numerous publications by V. Afonkova, G. Antonov, S. Banykina, 
V. Basov, T. Chistyakova, O. Ionova, E. Durmanenko, T. Dzyuba, V. Kazanskaya, E. Kirshbaum, J. Kolomiysky, A. Likhanov, G. Lozhkin, M. Piren, N. Povyakel, L. Porokhni, M. Rybakova, V. Semichenko, L. Simonov, O. Sokolova, S. Suleymanova, G. Shevchenko, N. Shchurkova, N. Shelyakhovskaya, E. Tonkova, T. Turkot, I. Vashchenko, B. Zhiznevsky, V. Zhuravlev, and others. L. Simonova, having analyzed the modern psychological and pedagogical literature, concluded that practical studies of pedagogical conflicts develop, mainly, in two directions: the study of conflicts in the system "student-student" and in the system "teacher-student" [10, p. 218-219].

Foreign scientists of the past have made a significant contribution to the development of methodological and general theoretical aspects of the problem of the use of art therapy (R. Arnheim, K. Burke, B. Elkonin, A. Hill, Z. Freud, A. Freud, K. Jung, J. Moreno, M. Naumburg, S. Rubinstein, L. Vygotsky, D. Vinnicot, etc.) and the present (J. Alan, V. Appleton, V. Auckland, G. Fers, G. Hulbut, I. Jacob, E. Kelisch, O. Kopitin, T. Koloshin, L. Lebedev, R. Martin, M. Wilson, T. Zinkevich-Evstigneeva). They art therapy is understood as a set of psychological methods of influence, which are carried out in the context of the pictorial activity of the client and psychotherapeutic relationships, and involved in the treatment, psychocorrection, psychoprophylaxis, rehabilitation and training of persons with various physical disabilities, emotional and mental differences.

At the present stage of development, art therapy is an interdisciplinary field of knowledge that harmoniously combines theory and experience, the legacy of psychology, pedagogy, cultural studies, and medicine. The basis of art therapy is the artistic practice that clients engage in the process of art-therapeutic classes. Their main goal is to harmonize the individual by developing the capacity for selfexpression and self-knowledge [14, p. 145].

Today, many scientists-theorists and practitioners are researching the problems of art-therapy in our country: A. Breusenko-Kuznetsov, Y. Gundertaylo, L. Dvornichenko, L. Language, O. Miroshnichenko, L. Naydenova, O. Nakonechna, O. Pletka, V. Savinov, O. Sknar, V. Stadnik, O. Tararina, R. Tkach, O. Vasilevskaya, O. Voznesenskaya, N. Zabolotna, T. Yatsenko and others. In their opinion, art therapy meets the expectations, attitudes, traditions of clients in Ukraine, which are characterized by an orientation to emotional and imaginative experience, rather than a rational resolution of conflicts.

Research goal and objectives. The purpose of the article is to analyses and characterize the resources of art therapy in managing pedagogical conflicts in universities. To achieve this goal, the following tasks were implemented:

- the content, historical aspect, types, specifics of the use of art therapy in universities were analysed;

- revealed the essence, characteristics, dynamics, management of pedagogical conflicts;

- generalizes the types of art therapy in the management of pedagogical conflicts in universities.

Study presentation. Art therapy is a type of psychotherapy based on the intersection of art, creativity and science. Art therapy is a method of providing psychological help, where works of art, or the process of their creation, are used as a kind of therapeutic factor for the transmission of human emotions and feelings, various manifestations of human mental activity [6].

The basis of the modern definition of art therapy are the concepts of expression, communication, symbolization, with the action of which is associated with the artistic creativity of the individual. Art therapy is based on the fact that the created products of artistic creativity are able to help a person to understand himself, to reveal the most secret parts of his inner world, to solve various conflicts and to make his life full and happy through the creative process of expression [9, p. 7-8].

$O$. Miroshnichenko in his article "Features of the use of art therapy method as a way of self-regulation of psychoemotional state of prison staff" [16, p. 13] convincingly states that in a peculiar symbolic form: through drawing, play, fairy tale, music - a person is able to give way to his own strong emotions, intense experiences, to gain new experience in dealing with conflict and traumatic situations. Transferring your experiences from the real one into fictional fairy tales, plasticise or clay figurines or on a piece of paper in the form of a drawing - you can, in a completely different way, look at yourself, other people and your own life in general through the prism of irrationality. In the process of creative activity there is a feeling of emotional saturation, there is a deeper understanding of himself and his inner world.

Symbolic art originates from cave paintings of primitive people. In ancient times, our ancestors used symbolism to identify their place in the world space and search for the meaning of human existence. Art has always existed and has a socializing and therapeutic character.

Art therapy as an independent field in the medicalcorrective and preventive work has only a few decades of its existence. As a science-based, mostly empirical, method, it began to take shape around the middle of the XX century. At the initial stage of its formation, art therapy was used for the therapeutic purpose of patients.

As O. Nakonechna notes in her work "Art therapy as a way of influencing personality in foreign and domestic literature" [17, p. 158], the term "art therapy" was introduced by A. Hill in 1938 as a result of activity with tuberculosis patients as a way of their free personal expression. Initially, art therapy was based on psychoanalysis, according to which the final product of a client's creativity is regarded as an expression of unconscious processes occurring in his psyche. $Z$. Freud argued that the unconscious manifests itself in symbolic images. However, he himself did not use art therapy in dealing with patients and did not explicitly encourage patients to draw pictures. At the time, a closest disciple of Freud K. Jung was of the opinion, who urged patients to express their dreams and fantasies in drawings, considering them as one means of studying the unconscious. K. Jung plays a huge role in the development of those forms of psychotherapy that use the visual work of patients.

In the early twentieth century, ideas began to spread that "non-professional" rather than "high" art could be a means of renewal and healing. With the development of the movement for "children's art" grew interest in the "pathological art", which is the work of the mentally ill. Since then, the practice of collecting and studying the works of the mentally ill, as well as attempts to imitate it in their own work, have started.

The artist Jean Dubuffe managed to collect an extremely interesting collection of works of the mentally ill, which was exhibited in Europe and America and was able to attract the great interest of the public and professionals. His activities significantly influenced the views of contemporary artists. Some of them used is production of the mentally ill as a stimulus for their work and continued to engage in art therapy [6].

Further development of the art-therapeutic direction was also being prepared by the champions of the psychodynamic approach advocated by Margaret Naamburg. She is considered the founder of art therapy in the United States. She had a psychology degree, and then received a psychoanalyst specialization. M. Naamburg is known as the author of dynamic-oriented art therapy.

In the 40's of the twentieth century, she began to use drawing techniques in her psychoanalytic work with children, 
considering the child's free expression of her experiences in fine arts as a tool for exploring his unconscious processes. At the same time, this technique, as noted by M. Naamburg, can be used by a psychiatrist as a design tool for diagnosis. When the patient as a result of the exercise overcomes uncertainty and begins to freely express their fears, needs and fantasies, he comes into contact with his unconscious and "talks" to him symbolic "language" of images.

In his later works, M. Naamburg began to use the term "art therapy", mainly as a technique that allows a person to express their intra-mental conflicts in a visual form and gradually come to their realization and verbalization. M. Naamburg is also rightly considered the founder of arttherapeutic education in the United States. In the 1950s, she founded the first courses in art therapy and subsequently sought to transform them into a full-fledged postgraduate training program for art therapists [17, p. 158].

In Europe, Herbert Reed and Adrian Hill are recognized as the founders of art therapy. He is known not only for his work with patients as an art educator in UK hospitals, but also for his active promotion of therapeutic and rehabilitation artistic practice through the media, as well as his considerable organizational skills. For many years he was president of the British Association of Art Therapists.

In the second half of the 1940s and early 1950s, the first attempts by art therapists to unite and define their role more clearly took place. Thus, in 1949 the first art-therapeutic committee was founded, headed by A. Hill. At this stage of the development of art therapy, its most common forms were: - the use of art therapy in psychiatric hospitals in order to assess patients' condition and the dynamics of the healing process; - use of fine products of patients in somatic hospitals (including specialized long-stay clinics) mainly for ward decoration [16, p. 14].

In the 1950's, various segments of art-therapeutic direction were formed: art-therapy as a form of employment therapy, art-therapy in education, art-therapy as a means of psychotherapeutic work, and others. Their leaders often differently defined the content of art-therapeutic activities and even came into conflict with each other, because there was no clear idea of what art-therapy was and who such arttherapist was. At the same time, there was a clear desire for unification - the formation of professional associations.

In the early 1960s, which became a turning point for the development of the art-therapeutic specialty, the first professional associations of art-therapists were established in several countries. In 1963, the British Association of Art Therapists (BAAT) appeared. Soon the American Association of Art Therapists was formed.

In the 1970s, the British Association of Art Therapists made important steps towards integrating art therapy into the state health care system. At the same time some other specialized courses of art-therapeutic training were organized within the framework of postgraduate education.

In the 60-80's further development of the art-therapeutic approach led to clearer registration of the professional role of the art-therapist. The experience of artistic practice in the future was able to combine with the techniques of verbal psychotherapy and to implement in the context of the relationship of the patient and the art therapist, as well as differentiate different forms of art-therapeutic work, depending on its tasks and the nature of one or another group of patients [17, p. 158].

In the 1990s, scientific publications were printed, and conferences for specialists were organized. Web sites and electronic libraries appear on the Internet, as well as electronic publications dedicated to the art therapy.
Kinds of art therapy correspond to existing kinds of arts. Classical art therapy only involves visual arts, such as: painting, graphics, and photography, drawing and modelling. But modern art therapy has more types of techniques. These include fine arts therapy, music therapy, dance therapy, drama, fairy-tale therapy, librarianship, ethno-therapy, play therapy, colour therapy, phototherapy, puppet therapy, origami and more.

In addition, each of these types has many art-therapeutic techniques that are used to resolve internal and interpersonal conflicts, crises, age crises, injuries, neurotic and psychosomatic disorders, and the like. A complex method was developed - art synthesis therapy. It is based on the combination of painting, poetry, dramaturgy and theatre, rhetoric and plastics. Moreover, the number of techniques is constantly increasing. The most common types of art therapy: painting, game therapy, music therapy, fairy-tale therapy, dance-motor therapy, collage, bibliotherapy, sculpting, drama, phototherapy, sand therapy [7]

Today, there are many spheres where art therapy is used, and psychologists, psychotherapists, educators and social workers are studying it. Educators, teachers have always been carriers of high ideals, the embodiment of moral and ethical qualities, heralds of a new worldview. It is no accident that the term "higher education" denotes the process and result of the formation of the spiritual personality of the student's personality, improvement of his abilities, the development of individuality, the growth of social competence, when determining the future life of both the individual and the whole society as a whole [13, p. 90].

A leading principle in the development of modern higher education is the advanced development of the qualities of the student's personality, the most important role in ensuring the realization of which belongs to the university, as a social, philosophical and pedagogical phenomenon. Higher education is the answer to the challenges of the modern age. The university as an organization, a center of education and science, a cultural centre should not only impart knowledge to students, but also produce new ones by involving students in scientific search, teaching them to critically analyse, independently, freely, creatively think and act, formulate and solve new ones independently problems, develop and learn throughout life.

It is at universities that for centuries the scientific traditions of theoretical and empirical research, long-term multidimensional and in-depth experimental work have been preserved, cultivated and multiplied; original scientific schools are formed; acquire the development of teaching, theory, approaches, which are reflected in the curricula and educational programs for training specialists, in particular, and the educational sphere $[13$, p. 92].

Therefore, a competent specialist after graduation from the university should have a spectrum of knowledge and skills, be able to develop different ways to solve problems, conflict situations that confront him, as well as possess critical thinking that allows him to creatively choose the most optimal of all the proposed ways of developing conflict resolution.

In this process of particular importance are the achievements of art therapy, which is unfairly undervalued in the educational process of the modern university. Art therapy resources enable students at the symbolic level to experiment with different feelings, to explore and express them in a socially accepted form, developing a sense of inner control and conflicting competence. Also, art therapy is effective in correcting various deviations and disorders of a student's personal development by relying on the healthy potential of his or her personality. 
Summarizing the ideas of O. Miroshnichenko [16, p. 14] regarding the peculiarities of using the art-therapy method as a way of self-regulation of psycho-emotional state, we modify them for university students. We fully agree that modern art therapy has no limitations and contraindications, it is always resource and environmental in terms of application. The art therapy technique is based on the belief that the student's inner self is transformed into visual materialized symbolic images or specific constructs of artistic creativity each time he spontaneously, especially without thinking about what should come out in the end draws, photographs, listens to music, dances, collages or videos, and more. It is believed that images of artistic creativity reflect the content of subconscious processes, including internal conflicts, fears, intrusive thoughts, childhood memories, dreams, and more.

Because art therapy has no limitations, it is available to virtually every student. It is an extremely interesting work that does not require special abilities and artistic skills, which mobilizes the creative potential of the student, triggers the mechanism of mental immunity to self-healing and restores the processes of self-regulation and is able to change the outlook of the individual through positive filling. In the process of creative activity, our subconscious interacts with consciousness through created artistic images, and the process itself brings pleasure, teaches more arbitrarily and spontaneously to express our experiences. Art gives the opportunity to transform into a problem, in a veiled form, into a painting, a photo, a music piece, a dance, a collage, a video and other works of art, which the student was unaware of and was supplanted, bring out, analyses and find a solution for her.

Researcher, President of the All-Ukrainian Public Association "Art-Therapeutic Association" O. Voznesenskaya $[15$, p. 11-13] outlined in detail the specifics of the use of art therapy, which in the adapted version is typical for university students. Art therapy as a means of self-expression, which is decisive in the student's age, is based on the situation when students' verbal way of interaction is impossible (due to physical disabilities, fear or inability to express their thoughts in words). At this point, art therapy using the language of visual, plastic, and audio expression becomes indispensable. Art therapy as a means of free expression and self-knowledge is a tool of research and harmonization of those sides of the student's inner world for which there are no adequate verbal means.

On this basis $O$. Voznesenskaya [15, p. 11-13] convincingly proves that in the course of art-therapeutic process additional opportunities are created for intrapersonal communication, transition to deeper levels of interaction with the manifestation of internal (including unconscious) mechanisms of organization of behaviour. There is a release from the dominant patterns and ideology of the behaviour patterns and development of those roles that are most relevant to the deep nature, needs and directions of the student's development. In this context, art therapy performs creative, developmental and recreational, educational functions and is considered by the researcher and interpreted as creativity, pleasure, and learning.

Art therapy as creativity is that a sufficient level of creativity enables the student to find effective solutions and promotes personal professional self-realization and growth. Creativity is a step beyond knowledge, overcoming, and being free from limitations. The creative process is the process of creating a fundamentally new product, and the student's creativity is the ability to abandon stereotypical models of thinking and acting.
Art therapy as a pleasure emphasizes that creativity is inextricably linked to the concept of pleasure. Therefore, art therapy always gives a high positive emotional charge and is the most painless way to solve problems, conflicts of the student.

Art therapy as a training is a unique way to convey the human experience. Today in the science of this issue separate concept - art-pedagogy. The image becomes a tool of communication, and engaging in creative creativity activates and enriches human communicative and creative capabilities, contributes to the development of a wide range of new ways of communication, orientation to interpersonal interaction [15, p. 11-13].

We believe that the quality of education of university students will improve if art-pedagogy is implemented in the format of educational training. It involves the active use of business role-playing games, training exercises, which provokes and stimulates a high level of cognitive interest of students, their long-term interest and becomes one of the most productive effective interactive tools of the modern teacher.

The author's 15-year experience in conducting educational trainings demonstrates that considerable attention is paid to communication styles, conflict resolution strategies, mediation, the latest educational technologies, and pedagogical conflict resolution techniques that are becoming permanent, necessary companions of group dynamics and confirm the genesis of the training group [10]. Initially, training with resource therapy for art therapy involves intensive group work of students in the university's auditoriums, its Psychological Service, the Centre for Psychological Assistance, and more.

Next, students gain relevant experience in mastering specific types of art therapy, which in the future can go into individual classes with a teacher-art therapist. Then, at a higher personal level of student development, it is desirable that this activity be transformed into self-help, self-training with a focus on a more useful type of art therapy for the student.

Such self-help aims at mastering, managing emotions, feelings that become the trigger mechanism, the most important lever in pedagogical conflict. Self-help involves a thorough, in-depth work of students with emotions in the library hall, recreation rooms, co-working, and more. Particularly recent facilities are desirable to provide resources for art therapy. This will give students the comfort, confidence and positive potential to resolve pedagogical conflicts that were previously largely resolved casually in corridors, while smoking on the steps or outside the university, in the classrooms, etc.

In contrast, co-working is an area where students are managed solely according to their needs and without haste. Co-working is not only a space for intellectual development, student learning, but also an opportunity to learn to build constructive social relationships, to develop emotional intelligence, while preventing and resolving conflicts of various types with the help of art-therapy resources.

In the dynamics of pedagogical conflict, the stages can have different duration, significance and intensity. Studies conducted by reputable psychologists $[3,4,11,12]$ show that there are differences in duration and quality, the consequences of conflict, depending on how experienced opponents participate in it, and what methods of interaction they use when managing its process.

Management of pedagogical conflicts involves the algorithm of effective actions, a set of special levers and tools for ensuring the constructive development of the educational institution. Management of pedagogical conflicts is a process of interaction, a clearly logically modelled algorithm of actions of administration, teachers 
and students aimed at achieving the result through the most modern ways and means of educational activity, which is desirable to be carried out through the prism of appropriate educational socialization of students in higher education [13, p. 100]. The conflict actions of the opponents sharpen the emotional background of the pedagogical conflict, and emotions in turn stimulate the conflict behaviour, causing it to escalate. We have a closed circle, which is possible to break the resources of art therapy by timely self-help, autotraining in preventive work on emotions of the person at the initial stages of development of pedagogical conflict characterized by general patterns.

The main stages of managing pedagogical conflicts (generalized and modified by I. Vashchenko [2]):

1. The emergence and development of a conflict situation, which is created by one or more subjects of educational interaction and is a prerequisite for pedagogical conflict. In this process, the resources of art therapy in preventative work on the emotions of the individual and the ability to solve the problem in non-conflictual ways (persuasion, informing the opposing party, request, and suggestion) become crucial.

2. Awareness of the conflict situation with at least one of the participants in the educational interaction and his emotional experience, which is manifested in the change of mood, critical statements addressed to his potential opponent, reducing contact with him.

3. The beginning of open conflict interaction, characterized by joint active actions aimed at harming opponents.

4. The development of open conflict involves making public statements about their positions and the demands of their opponents, but at the same time, they may not be aware of their own interests and may not understand the nature and subject of the conflict. Open conflict involves the incident and escalation of the conflict, which is a sharp intensification of the struggle of the opponents, the invasion of emotions, which lead to an increase in perception errors.

5. Resolving a pedagogical conflict that involves moving from conflict resolution to finding compromise, cooperation and overcoming conflict [2].

The problem of conflict resolution by art therapy resources has been the subject of a separate study by wellknown Ukrainian art therapist Elena Voznesenskaya [15]. The researcher aptly states that the creative process is the main therapeutic mechanism that allows to deconstruct a conflict traumatic situation in a special symbolic form, to find a new form of its solution.

According to A. Voznesenskaya [15, p. 12-13], art therapy in conflict management:

- is a method of restoring the resources of the individual, overcoming the consequences of traumatic events, building new, more constructive models of behaviour in new conditions of life, activating the internal forces of the person for choice, directing one's own life;

- gives rise to internal conflicts and strong emotions, helps to understand their own feelings and experiences, promotes self-esteem and helps in the development of creative abilities;

- helps the person to expel blocked emotions (energy) and overcome fear, in order to open access to unconscious information, to widen his / her own internal borders, because images of artistic creativity reflect all kinds of unconscious processes, including fears, dreams, conflicts, memories;

- provides an opportunity to strengthen personal resilience, which is associated with the ability to overcome difficulties and the ability to self-sustain traumatic experiences, based on healthy self-confidence, purposefulness, sense of self-realization and potential of self-realization, equilibrium, good-naturedness.

For participants in the art-therapeutic process, art is not an end in itself; it is merely a means of helping one to understand oneself better. During the stage of resolving pedagogical conflict, art therapy techniques provide:

- socially acceptable way of aggression of the student, management of his anger and other negative feelings (taking pictures, drawing, listening to music, gluing, cutting paper during the creation of a collage is a safe way to release "steam" and relieve tension);

- facilitating a process of interaction in which unconscious internal conflicts and experiences of the student are often easier to express through visual images than to express them in the process of verbal correction;

- material for interpretation and diagnostic conclusions about the student;

- developing thoughts and feelings that the student is used to suppress;

- establishing relationships between the teacher and the student, when joint participation in artistic activities can foster relationships of empathy and mutual acceptance;

- developing a sense of internal control;

- focusing on the feelings and feelings of the student, which creates opportunities for experimentation with kinaesthetic and visual sensations;

- the development of artistic ability, the sense of satisfaction that arises as a result of revealing hidden talents and improving the student's self-esteem.

The author of the article conducted a pilot study, which was conducted during 2019 at the Institute of Philology, Kyiv National Taras Shevchenko University. The sample was 67 students aged 21 to 28 years full-time. According to the questionnaire conducted by students, overcoming pedagogical conflicts gives preference to the most convenient resources of art therapy, adapted to the realities of today: music therapy (29\%), phototherapy (25\%), painting therapy $(12 \%)$, bibliotherapy $(10 \%)$ (especially electronic) format), dance and movement therapy $(7 \%)$, collage $(4 \%)$ other types (13\%)

All these types of art therapy are harmoniously complemented by combined logotherapy with the use of virtual communication of social networks, which, from the students' experience, provides quality constructive result in solving pedagogical conflicts. Performance, drama, mediaart therapy in the format of blogging on various online platforms (YouTube, Instagram, Telegram channels) are all separate modern types of art therapy that helps creative expression, self-affirmation, self-actualization and selfhealing of the personality. This virtual art therapy (virtual therapy, online therapy) is intensively developing both in the world and in Ukraine, and is gaining a specific distribution and authoritative recognition of practitioners and scientists.

Our research shows that music therapy occupies the palm of primacy and is of great benefit to students. It is effective for conflicts, depressive states, stresses, sleep disorders and more. At present, music therapy is a significant psychocorrection direction, which has at its core two aspects of influence: psychosomatic (in the process of which a therapeutic effect on the body's functions is carried out) and psychotherapeutic (in the process of which correction of deviations in personal development, psycho-emotional state through music) [16, p. 15]. It is the healing effect of music that allows you to use it in correctional work with students.

Thus, music therapy is a set of techniques and techniques aimed at expanding and enriching the range of experiences and forming such an outlook that helps the 
student to be healthy and happy. In the process of listening to music works, the inner state of the individual acquires a positive dynamic. The student, listening to music, adjusts to the rhythm of the motive, absorbs the positive vibration and without much willpower effort corrects mood, improves the state of his emotional sphere.

For the same purpose, phototherapy has been used to solve various psychological problems, self-development and self-discovery of the individual. This type of art therapy is considered to be quite young, since its development began in the late 20th century in the United States.

Coryphaeus of art therapy in Russia O. Kopitin suggested the use of photography for therapeutic, corrective, developmental and preserving health. The availability of photography, as well as the variety of forms and variations of phototherapy sessions, make it possible to use this technique in working with people of all ages (from the age of three), regardless of their level of development and needs. O. Kopitin noted the positive impact of photography on the individual and his relationship with the environment. Such effect can be manifested, both at independent individual lessons, and in the course of creation of photos and their subsequent discussion with the specialist [8].

Photography is used in the work to solve various psychological problems, as well as for the harmonization and development of personality. The specialist develops a perspective plan of lessons, which is complemented by photos and art-therapeutic elements, exercises, games, fairy tales that allow creating an atmosphere of psychological comfort and emotional-sensory attitude of the person to the world. Phototherapy also applies additional visual techniques, such as collage, installation of readymade photos in the interior, work from the photos of models and further interaction with them, etc.

Conclusions. So, summarizing all the above, we conclude that the use of resources of art therapy provide creative expression, self-affirmation, self-actualization and self-healing of the individual, his psychological comfort and promote harmonious development, add positive potential in the constructive management of pedagogical conflicts. Creativity realized in the process of art therapy stimulates the ability to express and reproduce inner feelings, emotions, doubts, conflicts and hopes, enables in a symbolic form (spontaneous creative activity capable of expressing the unconscious content of mental life) experiencing once again more important events solve real problems.

The most scientifically substantiated and significant advantages of art therapy in the management of pedagogical conflicts in universities are that art therapy: provides a socially acceptable outcome of aggression and other negative feelings of personality; creates a positive emotional mood, forms an active life position, selfconfidence; facilitates the process of communication, when unconscious internal conflicts and experiences are often easier to express through visual images than to express them in the process of verbal correction and non-verbal communication is easier to escape from the censorship of personality consciousness; enables to symbolically experiment with different feelings, to explore and express them in a socially accepted form; develops a sense of internal control; effective in the correction of various deviations and disorders of personal development, relies on the healthy potential of the individual; develops artistic abilities, raises self-esteem, arouses feelings of satisfaction resulting from the identification of hidden personal talents.

\section{References}

1. Antonov H. V. Pedahohichni zasady zapobihannya i rozv"yazannya konfliktiv u navchal'no-vykhovnomu seredovyshchi vyshchoho navchal'noho zakladu: avtoref. dys. na zdobuttya nauk. stupenya kand. ped. nauk: spets.
13.00.04 teoriya i metodyka profesiynoyi osvity / Antonov H. V. - Kharkiv. 2006. $-20 \mathrm{~s}$.

2. Vashchenko I. V., Klyap M. I. Konfliktolohiya ta teoriya perehovoriv. Navchal'nyy posibnyk. - K.: Znannya, 2013. - 407 s.

3. Haluzyak V. M., I. L. Kholkovs'ka. Pedahohichna konfliktolohiya. Navchal'ny posibnyk. - Vinnytsya: "Nilan", 2015. - 208 s.

4. Hirnyk A. M. Osnovy konfliktolohiyi. Navchal'nyy posibnyk. - Vyd-vo "Kyyevo-Mohylyans'ka akademiya", 2010. - 222 s.

5. Klymenskykh M. V. Pedahohycheskye konflykty v shkole. Ekaterynburh: Yzd-vo Ural. un-ta, 2015. - 76 s.

6. Kopytyn A. Y. Sovremennaya klynycheskaya art-terapyya. Uchebnoe posobye. - M.: Kohyto-Tsentr., 2015. - 526 c.

7. Kopytyn A. Y. Art-terapyya - novye horyzonty. - M.: Kohyto-Tsentr, 2006. - $336 \mathrm{~s}$

8. Kopytyn A. Y. Trenynh po fototerapyy. - SPb.: Rech', 2003. - 96 s.

9. Kopytyn A. Y. Art-terapyya v épokhu postmoderna. - SPb.: Rech', 2002. $-224 \mathrm{~s}$.

10. Koshechko N. V. Efektyvna profesiyno-pedahohichna komunikatsiya vykladacha ZVO: profilaktyka ta rozv"yazannya pedahohichnykh konfliktiv u vitchyznyaniy vyshchiy shkoli // Profesiyno-pedahohichna pidhotovka vykladachiv: Kolektyvna monohrafiya / hol. red. A. A. Marushkevych. - K.: VPTS "Kyyivs'kyy universytet", 2018. - S. 217-269.

11. Piren M. I. Konfliktolohiya: Pidruchnyk. - Kyyiv: MAUP, 2007. - 360 s.

12. Turkot T. I. Pedahohichna konfliktolohiya // Psykholohiya i pedahohika vyshchoyi shkoly v zapytannyakh i vidpovidyakh: navch. posib. dlya stud. VNZ / T. I. Turkot; [M-vo osvity i nauky Ukrayiny]. - Kyyiv, 2011. - S. 145-162.

13. Koshechko N. V. Actual ideas of pedagogical conflictology for preparation of educational professionals in domestic classical universities // Professional and pedagogical training of educational specialists in classical university of Ukraine: multi-authored monograph / Ed. by Marushkevich A.A. - LAP LAMBERT Academic Publishing, 2019. - R. 89-110.

14. Vasylevs'ka O. I., Dvornichenko L. L. Metody art-terapiyi u konsul'tuvanni. [Elektronnyy resurs]. - Rezhym dostupu: http://www.tpspjournal.kpu.zp.ua/archive/1 2019/part 1/31.pdf

15. Voznesens'ka O. L. Art-tek̄hnolohiyi u rozv"yazanni konfliktiv. [Elektronnyy resurs]. - Rezhym dostupu: http://uhrf.org/download/42.pdf

16. Miroshnychenko O. M. Osoblyvosti zastosuvannya metodu art-terapiyi yak sposobu samorehulyatsiyi psykhoemotsiynoho stanu penitentsiarnoho personalu [Elektronnyy resurs]. - Rezhym dostupu: http:/NchdpuPH 2014 121(2) 5.pdf

17. Nakonechna O. V. Art-terapiya yak sposib vplyvu na osobystist' u zarubizhniy ta vitchyznyaniy literaturi. [Elektronnyy resurs]. - Rezhym dostupu: http://oaji.net/articles/2014/365-1393508681.pdf

\section{Список використаних джерел}

1. Антонов Г. В. Педагогічні засади запобігання і розв'язання конфліктів у навчально-виховному середовищі вищого навчального закладу : автореф. дис. на здобуття наук. ступеня канд. пед. наук: спец. 13.00.04 теорія і методика професійної освіти / Антонов Г. В. - Харків. 2006. - 20 с.

2. Ващенко І. В., Кляп М. І. Конфліктологія та теорія переговорів : навч. посіб. - К.: Знання, 2013. - 407 с.

3. Галузяк В. М., І. Л. Холковська. Педагогічна конфліктологія : навч. посіб. - Вінниця: "Нілан", 2015. - 208 с

4. Гірник А. М. Основи конфліктології : навч. посіб. - К. : вид-во "КиєвоМогилянська академія", 2010. - 222 с.

5. Клименских М. В. Педагогические конфликты в школе. - Екатеринбург : Изд-во Урал. ун-та, 2015. - 76 с.

6. Копытин А. И. Современная клиническая арт-терапия : учеб. пособ. М.: Когито-Центр., 2015. - 526 с.

7. Копытин А. И. Арт-терапия - новые горизонты. - М.: Когито-Центр, 2006. $-336 \mathrm{c}$

8. Копытин А. И. Тренинг по фототерапии. - СПб.: Речь, 2003. - 96 с.

9. Копытин А. И. Арт-терапия в эпоху постмодерна. - СПб.: Речь, 2002. -224 C

10. Кошечко Н. В. Ефективна професійно-педагогічна комунікація викладача 3ВО: профілактика та розв'язання педагогічних конфліктів у вітчизняній вищій школі // Професійно-педагогічна підготовка викладачів: Колективна монографрія / гол. ред. А. А. Марушкевич. - К.: ВПЦ "Київський університет", 2018. - С. 217-269.

11. Пірен М. І. Конфрліктологія : підручник. - Київ: МАУП, 2007. - 360 с.

12. Туркот Т. І. Педагогічна конфліктологія // Психологія і педагогіка вищої школи в запитаннях і відповідях : навч. посіб. для студ. ВНЗ / Т. І. Туркот; [М-во освіти і науки України]. - Київ, 2011. - С. 145-162.

13. Koshechko N.V. Actual ideas of pedagogical conflictology for preparation of educational professionals in domestic classical universities // Professional and pedagogical training of educational specialists in classical university of Ukraine: multi-authored monograph / Ed. by Marushkevich A.A. - LAP LAMBERT Academic Publishing, 2019. - P. 89-110.

14. Василевська О. І., Дворніченко Л. Л. Методи арт-терапії у консультуванні. [Електронний ресурс]. - Режим доступу: http://www.tpspjournal.kpu.zp.ua/archive/1_2019/part_1/31.pdf

15. Вознесенська О. Л. Арт-технології у розв'язанні конфліктів. [Електронний ресурс]. - Режим доступу: http://uhrf.org/download/42.pdf

16. Мірошниченко О. М. Особливості застосування методу арт-терапії як способу саморегуляції психоемоційного стану пенітенціарного персоналу [Електронний ресурс]. - Режим доступу: http://NchdpuPH_2014_121(2)_5.pdf

17. Наконечна О. В. Арт-терапія як спосіб впливу на особистість у зарубіжній та вітчизняній літературі. [Електронний ресурс]. - Режим доступу: http://oaji.net/articles/2014/365-1393508681.pdf

Надійшла до редколегії 10.01.20 
Н. Кошечко, канд. пед. наук

Київський національний університет імені Тараса Шевченка, Київ

\section{РЕСУРСИ АРТ-ТЕРАПІЇ В УПРАВЛІННІ ПЕДАГОГІЧНИМИ КОНФЛІКТАМИ В УНІВЕРСИТЕТАХ УКРАЇНИ}

У статті проаналізовано актуальні ідеї з проблеми розв'язання педагогічних конфліктів студентами, які використовують ресурси арт-терапії. Це напрям наукового знання призначений допомогти особистості усвідомити свій внутрішній стан шляхом створення нею візуального образу, метафор, символів, відеороликів (арт-терапевтичного продукту); ие розвиток у особистості властивої їй креативності, що допомагає при вирішенні конфліктів. Через творче самовираження арт-терапія актуалізує особистісні ресурси для подолання педагогічних конфліктів та дає вихід накопиченій енергії (агресії), тим самим гармонізує емоційну сферу. Створюючи абстрактні образи, студент знаходить відповіді на багато актуальних питань, досліджує страхи і бар'єри у спілкуванні. Ці образи виникають несвідомо і спонтанно, саме тому знижується тривожність і опір до самопізнання. Таким чином забезпечується різноманітній спектр інструментарію для роботи з емоційною сферою особистості. Apm-терапія дає конкретну відповідь на глобальне питання "Як приборкати емоції у конфлікті?". У цьому контексті проаналізовано зміст, історичний аспект, специфіку арт-терапії у студентів та розкрито сутність, характеристику, динаміку педагогічних конфліктів. Узагальнено види арт-терапії у розв'язанні педагогічних конфліктів студентів університетів. Згідно із проведеним анкетуванням студентами при подоланні педагогічних конфліктів надається перевага таким видам арт-терапії: музикотерапія (29\%), фототерапія (25\%), ізотерапія (12\%), бібліотерапія (10\%) (особливо у електронному форматі), танцювально-рухова терапія (7\%), колаж (4 \%) інші види (13\%). Вони гармонійно доповнюються комбінованою логотерапією із використанням віртуальної комунікації соціальних мереж, що, з досвіду студентів, забезпечує якісний конструктивний результат і у вирішенні педагогічних конфліктів. Перформанс, драматерапія, медіа-арт-терапія у форматі блогінгу на різних інтернетплатформах (YouTube, Instagram, Telegram-канали) стають окремим сучасним видом арт-терапії, що допомагає творчому самовираженню, самоствердженню, самоактуалізації та самозціленню особистості студента.

Ключові слова: арт-терапія, управління педагогічними конфліктами, університет.

UDK 378

DOI: https://doi.org/10.17721/2415-3699.2020.11.04

N. Kuzmenko, Doctor of Pedagogical Sciences, Professor A. Ostapenko, postgraduate student Taras Shevchenko National University of Kyiv, Kyiv, Ukraine

\section{PEDAGOGIC IDEAS FOR STUDENTS OF INDEPENDENT WORK WITH THE BOOK}

The article analyzed the works of scientists (Avtomonova P. P., Boyko Y. V., and Zaichenko I. V., Zenkin A. S., Karandasheva V. N., Kirdyaeva V. M., Kuzmenko N. M., Lasch A P., Lvov I. P., Pylhaeva F. P.. Pogrebna Ya. A., Czerniawska A. P.), who developed methods of optimal study book, textbook and other paper media. Types of independent work with the coursebook, additional materials are necessary to have when studying or reading books and other manuals. Selected types of readers (based on lectures "Students' independent work with the book" by I.P. Lvov), the preferences of readers on the nature of the literature and recommendations for its choice.

It is substantiated that, according to I. P. Lvov, the book plays an important role in the development of thinking and speech culture of students. The Ukrainian teacher singled out four groups of students. Representatives of the first group are only interested in the reading process. To the second group of readers I. P. Lvov included people who like to read adventure literature and detective stories. The third group consisted of readers who are interested in serious, scientific literature, new books of modern bookstores. To the fourth type of readers, the scientist referred those who seek knowledge and therefore makes serious demands on the book.

It is proved that the Ukrainian teacher emphasized that the effectiveness of reading books is possible if the reader has a system of knowledge in a particular field, has the skills of good orientation in the text with the selection of basic principles and ideas. The result of mental work should be clearly designed in the form of writing or speaking, and the effectiveness of the process of working with the book depends not only on speed but also on the method of reading.

Keywords: independent work, book, textbook, student, lecture.

Formulation of the problem. If the wrong approach to reading literature of different genres and types there is a high probability of incorrect comprehension of the material or misunderstanding. It is very important that the students were explained the correct method of reading books with the point of view of better adoption of the material.

Scientists were developed a number of techniques for better adoption of information by students, which they subsequently could use in lectures, at seminars or during a conversation among themselves. It is necessary that students and other readers filtered print, sharing it on the main and secondary.

Research goal and objectives. To carry out the analysis of scientific works of scientists, who researched individual work of students with the book and the following tasks: to analysis a productive assimilation of material by students during independent reading books, manuals, etc.; to find an approach to reading books; show auxiliary means during the reading of the manuals.

Study presentation. With the correct reading can successfully build their future life. A number of researchers have developed methods of self-study, lecture material, textbooks, tutorials, or just reading fiction and nonfiction. Based on the writings of researchers we have analyzed several developments in the independent processing of the books.

Doctor of pedagogical Sciences N. M. Kuzmenko in the article "I. P. Lvov on students independent work with the book", on the basis of archival materials in the Public Record Office of Chernihiv region, analyzed the materials of the lecture on independent work of students So, N. M. Kuzmenko said that "I. P. Lvov believed that the book plays an important role in the development of thinking and speech. The readers of the lecturer were divided into four groups. Representatives of the first group are only interested in the reading process. Such readers are pupils, students, ordinary citizens. In conditions of this group can be refered that young readers who were learning to read:" [4, p. 201].

The second group of readers, according to. P. Lvov was persons who love to read for leisure, adventure books, novels criminal nature.

The third group of readers.I. P. Lvov was described as such who was interested in serious, scientifical literature, the novelties of modern bookstores. Unfortunately, the book is for those representatives is only a material for a conversation among friends to demonstrate their knowledge [4, p. 201]. 